\title{
THE WORK "FIRDAVS UL-IKBAL" IN RESEARCHES AND TRANSLATIONS OF RESEARCHERS IN THE SECOND HALF OF XIX-XX CENTURIES
}

\section{Bunyad Kh. Saparbaev}

A Master's Degree Holder in History, A teacher at The Faculty of History, Urgench State University named after Al-Khorezmi, Urgench, Uzbekistan

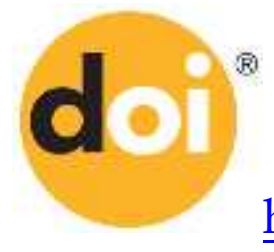

http://dx.doi.org/10.26739/2573-5616-2017-8-8-6

Abstract. The article considers the significance of the work "Firdavs ul-Ikbal" as an irreplaceable historical and literary source on the history of the Khiva Khanate. The history of the study of the work is covered and the works of its researchers H.Vamberi, A.L.Kun, Abraham Amirkhanyants, W.W.Bartold, P.P.Ivanov, Yu. Bregel and other scientists are reviewed. The author in the article gives information about the Leiden edition of the work carried out in 1988 by the historian Yu. Bregel and on the publication of 2010 in the Uzbek language. It is concluded that this work plays a big role in the study of the history of Khiva Khanate.

Keywords: work "Firdavs ul ikbal", The Khiva Khan Muhammad Rakhimkhan I, Munis, Agahi, H.Vamberi, A.L.Kun, pastor Abr. Amirkhanyants, W.W.Bartold, P.P.Ivanov, Yu. Bregel.

During the reign of one of the Khans of Khiva Abulgazi, the historical annals started to develop intensively in Khorezm. In contrast, during the rule of Muhammad Rakhimkhan I, this tradition rose on a new step. The work considered by us «Firdavs ul ikbal» is a work of the period of his stay on the Social science and humanities Generalization of scientific results 

Khan's throne. The focal point of this article is to convey the set of opinions about the given historical work, its separate events, and mainly about Muhammad Rakhimkhan I.

One of the foreign orientalists, who have left valuable data on Munis, Agahi, and also their work «Firdavs ul ikbal» is Herman Vamberi. It is necessary to notice that during H.Vamberi's expedition, the historian, chronicler Agahi was alive. The missionary notices that he got acquainted with Munis and his nephew Agahi who translated at this time historical products of Mirhond. Actually, Munis died in 1829 from cholera. Probably, Vamberi mixed up another person with Munis. The basic merit of the missionary is that he presented the name of Agahi to Europe.

It is necessary to pay attention to that circumstance as H.Vamberi describes cultural life of that time, provides ethnographic data. In particular, he writes about the peoples of Khiva: "Despite centuries-old age of a city, Khivan customs bear the stamp of former heroic life. Very often, there are demonstrative battles, fights, and especially horse jumps with magnificent prizes. Each considerable wedding does not do without races. The winner receives on 9, 19 or 29 pieces from any kind of property, for example 9 sheep, 19 goats etc. From former inhabitants of the country, fire-worshippers, holidays and games" have remained in Khiva (Vamberi, 1865, p. 172).

Most likely, the Hungarian traveller heard this from lips of Agahi or other representatives of intelligency. Besides it, he received the collection of verses of Munis by Agahi, which he intended to publish in German. In G.Vamberi's book, it is noticed that during the reign of Said Muhammadkhan, the level of cultural and political-economical life even more raised in the Khanate. The second person that obtained historical annals of Munis and Agahi was A.L.Kun, who in 1873 personally participated in the confiscation of books from the khanate library.

Under the manuscript («of the historical annals») of Munis and Agahi, A.L. Kun left his notes about the Khanate of Khiva with a summary of events from the period of Abulgazi to Muhammad Rakhimkhan II. In the article of the newspaper "Turkestan Sheets", A.L. Kun mentioned that he personally participated in the confiscation of historical "Firdaus ul ikbal" (Kun, 1873, p. 158). The text of article by A.L.Kun "Notes about the Khanate of Khiva" is fully given in U.Bekmuhammad's book: "During Khivan expedition, I collected the following scientific materials: 300 books, consisting of east manuscripts. From them, 129 - with the title. 140 volumes of historical manuscripts; the divans of east poets, consisting of 30 volumes; 50 volumes of religious books. Besides, 18 copies of "Koran", 50 textbooks. The documents available in the library were confiscated as well. These documents can be Social science and humanities Generalization of scientific results 

divided into two groups. In the first group, it is conditionally possible to include writing-books where incomes and khanate expenses were fixed, while the latter includes letters and diplomatic censuses...

Among these documents there were some requests of the peoples of Khiva, living in Bukhara, Gazali, Istanbul. They applied to the khan with the request to resolve any problem or to be appointed to some post. Among diplomatic documents, there was a letter of the governor-general of the East India Norsbruk, letters and decrees of the Turkish sultan, the written agreement signed between the Khivan khan and the Russian ambassador Lieutenant Colonel Danilevsky, and also some letters of the Turkestan governor-general "(Institute of Oriental Manuscripts of Russian Academy of Scineces, Fund 33, Shelf 16). Orientalist Kun brought these values to Tashkent and got acquainted with them partially, then gave them to the Petersburg national library, the museum of Asian Academy of Sciences (Bekmuhammad, 2012, p.151).

In a note of the pastor Avraam Amirhanjant «Firdavs ul ikbal», obtained by him from the Orenburg Tatar, it is informed on the advantages of the manuscript«: «the book is written accurately, cleverly, quite competently and coherently. All of its 906 pages can be read from the first up to the end in an unceasing and free way». In some scientific sources, there are general data on the records of the pastor Amirhanjant, and this encouraged us to familiarize ourselves with it in more detail. The note was written in 1890 and begins with a phrase: "It is well-known for Orientalists that it is rare for any manuscript to satisfy the most modest requirements of the scientist assorting it, when, whom, where and under what circumstances they are written. But the book « Firdovs ul-ikbal »answers all this sort of questions itself without forcing the reader to resort to conjectures and guesses».

The record consists of 18 pages with a reviewed character. Based on the source, Amirhanjant provides data briefly in six sections: 1) about authors of a source; 2) about the writing history; 3) about the structure; 4) about the language; 5) about the advantage of "Firdovs ul-ikbal"; 6) about the given manuscript; and in conclusion, - about a condition of acquisition of the book. In the end, there is a separate note about the record of prof. N.I. Veselovsky. Giving an example from the words of Munis, Amirhanjant writes: «... The aspiration to a science won by the scientists and he alternated between the poetry and the history. However, the author of « Firdovs ul-ikbal » is mainly famous for the verses as one of the first, if not the very first poet, and as the exemplary writer and as the classic historian. Sheikh Sulajman in his Chaghataic dictionary impartially refers to Munis, and after him, to Agahi, the nephew of our author».

Social science and humanities

Generalization of scientific results 
Concerning the history of the work, Amirhanjant writes that Iltuzarhan (1219/1804-1221/1806) oedered Munis, as the most capable scientist, to describe the acts made already by the khan, and what the khan intended to undertake for his glory. "Having continued, thus, the work to 638 pages, the historian passed away. Mohammed Riza Mirab Agahi finishes the remarkable work deservingly, having written 280 more pages. It is interesting to read about this by the completer of the work Agahi (pp. 638-640). The author names Agahi as the successor of style of Munis in a direction and originality, and he is said to be a worthy successor. Having written about the composition of the work, Amirhanjant deeply estimates the skill of Munis: " it is also important that the disposition which was taken by the first historian as a principle the work, and then the performance of the foreordained plan is followed by the death of Iltuzarhan and the successor Mohammed Rakhimkhan (1806-1825) wishes that his reign also enters into history. Munis had a deep ability to connect together, what according to an initial plan was not supposed and was not expected, but in essence the work makes a single whole».

Amirhanjant calls Munis as a historiographer and writes that, reading his book, it is possible to receive full representation about all actions of Abulgazihan, the son of Arabhan. «The orientalists of the whole world would wish to know willingly what exactly happens after 1074 khidjri in Khiva and in neighboring countries, till which time narrated Abulgazihan. Now we read, how nicely historian Munis describes the reign of Abulgazihan, Anushahan, one behind another represents us the historian, all masters who have followed Abulgazihan of Khiva till 1221 khidjri».

Having read the book carefully, Amirhanjant defines the following advantages of the history in «Firdaus al-ikbal»:

a) The completion of the history of Abulgazi Bahadurhan;

b) The replenishment of the blanks in the history of Abulgazihan omitted by this eminent historian, because their maintenance did not concern directly to that line of the history, which it kept for the special purpose. However, in the work of Munis we meet many events preceding the reign of Abulgazihan, which are parallel to his reign, but not mentioned;

c) The biographies of the remarkable people playing some obvious role in the given districts;

d) Interesting messages concerning the geography of sandy steppes, Aral Sea, an initial current of Amu Darya and the tap of their directions in the reign of Hadzhimhan (pp. 524 526); about some remarkable channels Shahabadarig (p. 825), but in particular about Bend Sultan (p. 880), which was paid attention by Mohammed Rakhimkhan specially and at which Social science and humanities

Generalization of scientific results 

restoration he paid with the life of Kutlug Murad inaq - the brother of the khan;

e) Certain, and clearly outstanding chronology, under the whole book, that put all materials on a strong basis of the facts;

f) The absence of superstitious explanations and superfluous deviations from a historical statement;

g) Carefulness in material collecting, both written, and orally;

From words of the author, it can be followed that in this book all materials are in respective history of the book, which existed during the work "Firdovs ul-ikbal" and that it is vain to search in all subject for any documents or oral legends.

h) Its syllable is strictly scientific, purely classical, and verses represent us classicism of Chagatai language in the higher perfection.

i) The work is written accurately, competently and coherently. All 906 pages can be read from beginning to end on one spirit, as product of the outstanding European scientist printing personally the work. This impeccability also urges to be convinced by polishing of a draft variant that author Agahi himself wrote this book. From all of this, it is possible to draw conclusions that it is the original and rather possibly single copy of this work. Berezin, baron Demizon, Fren, Ilminsky would consider themselves happy, if they had in hands the similar perfect manuscript at the edition of the Chaghatai sources ». Then the author writes about what the book lacks. «A lack of our copy - one and only. Of sheets nearby ten are torn » (Munirov, 2002, pp.13-15).

It is possible to notice that the note of Pastor Avraam Amirhanjant is valuable and interesting both to the usual reader, and for the expert. However, the data about the author, except records, neither in bibliographies, nor in the scientific and religious literature cannot be found yet. After A.L.Kun and pastor A.Amirhanjant, V.V.Bartold was interested in the work of Munis and Agahi "Firdaus ul-ikbal". He prepared the collection of the text of this work, but the censorship of the Soviet period did not give the permission to the work publication. As V.V.Bartold confirms, the work of Munis and Agahi, which are in archive of L.A.Kun, was bought by the representative of a museum of Asian Academy of Sciences and from its successors. Among them, there are the manuscripts in detail describing events in khanate until 1872. These materials are not published until now (Bartold, 1964, p.57). In 1900, V.V.Bartold defended the dissertation on a theme «Turkestan during an epoch of the Mongolian invasion». After that, in 1902 he came to Tashkent to collect historical manuscripts for the second time. As the academician Krachkovsky writes, in 1930th years the oriental Social science and humanities Generalization of scientific results 

studies was enriched with invaluable researches. It is necessary to mark that the strong base of these researches was put by V.V.Bartold and it concerned the history of Khorezm. Khorezm is regarded by the scientist as a cradle of an ancient civilization and attracted them. Many most valuable data on the Khanate of Khiva was found in his personal archive. Among his hand-written heritage, the history of Khiva city was found. His manuscripts consist of 200 pages. At studying the history of Khoresm, V.V.Bartold gives the special preference to historical works of Munisa and Agahi. He wrote:" Whatever minuses the work of Munis and Agahi has, as literary and historical work, this work expresses a detail a statement and the quantity of an actual material and far reserves all works which have reached us on stories of khanates of Bukhara and Kokand "(Bartold, 1927, p. 113). in 1929, the scientist separately collected data from the work of Munis and Agahi, concerning the Turkman, and carried out original researches. At the same year, in Berlin he found the new manuscript about the history of Khorezm and its data he compared with the events described in "Firdaus ul-ikbal" (A new source on stories of Khoresm. VIII volume, 1929, pp. 566-577). Thus, V.V.Bartold propagandised the work of Munis and Agahi" Firdaus al-ikbal "in the West. Other scientist P.P.Ivanov evaluated the work of Munisa and Agahi as the basic source on stories of the khanate of Khiva at XVIII-XIX centuries (Ivanov, 1958, p.56). He translated those parts of the book "in Firdaus al-ikbal" which concern stories of Turkmen tribes and used this source in work "Sketches on stories of Central Asia at the ages of XVI and middle XIX", which was published in 1958. In his data the special accent is placed on migration process. P.P. Ivanov being based on a source "Firdaus ul-ikbal" provided the detailed data on time of the reign of Muhammad Rakhimkhan I. The historian noticed that the khan spent the specified period also for land reform. The large landed property was almost liquidated. The lands were confiscated in favour of the state or distributed between representatives of the formed aristocracy. The given product was translated into English in 1988 by historian Yu.Bregel (Bregel, 1988). Finally, in 2010, it was presented in a full edition for readers in Uzbek language (Zhumahodzha N., Ruzimbaev S, Ahmedov A., 2010).

In the conclusion, it is possible to say that nowadays the process of studying "Firdavs ul ikbal" is proceeding by foreign and Uzbek scientists. Among Uzbek scientists, there are Ruzimbaev S., Ahmedov A., Hudoyberganov K., Hollieva G., Mutalov O., Matniyozov M. and others, who investigate the philological and historical sides of the given work. Thus, on an extent more than century, the work "Firdavs ul ikbal" was the focus of attention of researchers and through them, it played a big role in studying the history of the Khanate of Khiva as well.

Social science and humanities

Generalization of scientific results 


\section{References}

1. Vamberi H. (1865) Travel across Central Asia. Moscow

2. Kun A.L. (1873). Notes about Khivan khanate//Turkestan Sheets, № 40. Tashkent

3. Bekmuhammad U (2012). Souls fascinated by Khoresm. Tashkent

4. Munirov K. (2002). Historiography in Khorezm (XVII-XIX and the XXcentury beginning).Tashkent

5. Bartold V.V. (1964). Composition. V. 2. P. 2. Works on separate problems of history of Central Asia. Moscow

6. Bartold V.V. (1927). The history of cultural life in Turkestan. Leningrad

7. A new source on stories of Khoresm. VIII volume. (1929). Moscow p. 566577

8. Ivanov P.P. (1958). Features on stories of Central Asia. XVI middle XIX centuries. Eastern Literatures Publishing house. P.56. Moscow

9. Bregel Yu. L.. (1988). Firdavs ul ikbal. History of Khorezm. New York

10. Zhumahodzha N., Ruzimbaev S, Ahmedov A.. (2010). Shermuammad Munis Khorazmi, Muhammadrizo Ogahi. "Firdavs ul-ikbal". Oktuvchi. Tashkent 